\title{
Cadmium bioaccumulation and oxidative-stress- induced DNA alterations in the freshwater cladoceran Moina macrocopa (Straus 1820) following consecutive short-term exposure assessments
}

Thilomi Samarakoon ( $\nabla$ thilomir@kln.ac.lk)

University of Kelaniya https://orcid.org/0000-0003-2859-2223

Takeshi Fujino

Saitama University Graduate School of Science and Engineering: Saitama Daigaku Daigakuin Rikogaku Kenkyuka

\section{Masayori Hagimori}

Mukogawa Women's University: Mukogawa Joshi Daigaku

Rie Saito

University of Georgia

\section{Research Article}

Keywords:

Posted Date: February 9th, 2022

DOI: https://doi.org/10.21203/rs.3.rs-1333898/v1

License: (c) (1) This work is licensed under a Creative Commons Attribution 4.0 International License. Read Full License 


\title{
1 Cadmium bioaccumulation and oxidative-stress-induced DNA alterations in
}

2 the freshwater cladoceran Moina macrocopa (Straus 1820) following

3

4

5

6

7

8

9 10

Thilomi Samarakoon ${ }^{1,2}$. Takeshi Fujino' ${ }^{1}$ Masayori Hagimori ${ }^{3}$. Rie Saito ${ }^{4}$

${ }^{1}$ Department of Environmental Science and Technology, Graduate School of Science and Engineering, Saitama University, 255 Shimo-okubo, Sakura-ku, Saitama 338-8570, Japan

${ }^{2}$ Department of Zoology and Environmental Management, Faculty of Science, University of Kelaniya, Kelaniya 11600, Sri Lanka

${ }^{3}$ Laboratory of Analytical Chemistry, Faculty of Pharmaceutical Sciences, Mukogawa Women's University, 1168 Koshien Kyubancho, Nishinomiya 663-8179, Japan

${ }^{4}$ Savannah River Ecology Laboratory, University of Georgia, Aiken, SC, 29802, USA

Corresponding author - Takeshi Fujino - fujino@mail.saitama-u.ac.jp

ORCIDs of the authors

Thilomi Samarakoon - 0000-0003-2859-2223

Masayori Hagimori - 0000-0002-2371-911X

\begin{abstract}
Moina macrocopa is a toxicologically less explored, yet widely distributed freshwater cladoceran found throughout the world. The present study is aimed at determining the cadmium $(\mathrm{Cd})$ bioaccumulation and $\mathrm{Cd}-$ induced molecular and biochemical biomarkers, including DNA damage and antioxidant enzyme responses (i.e., catalase (CAT) and glutathione S-transferase (GST) activities), in M. macrocopa neonates. Cd bioaccumulation was determined using a Cd-sensitive fluorescence probe after acute exposure to $\mathrm{Cd}$. The results indicated a concentration-dependent $\mathrm{Cd}$ bioaccumulation, especially in the gut region, where it was statistically significant in neonates exposed to $\geq 5 \mathrm{Cd} \mu \mathrm{g} / \mathrm{L}$. DNA damage was determined by the randomly amplified polymorphic DNA (RAPD) technique after a short-term exposure to sublethal Cd concentrations. Significant DNA alterations were observed in individuals exposed to $\geq 10 \mathrm{Cd} \mu \mathrm{g} / \mathrm{L}$. Short-term exposure to sublethal Cd concentrations did not change CAT levels. However, low Cd concentrations $(10 \mu \mathrm{g} / \mathrm{L})$ significantly induced GST levels, and higher concentrations $(50 \mu \mathrm{g} / \mathrm{L})$ significantly inhibited the GST levels. Taken together, the results of the present study indicated that bioaccumulation of $\mathrm{Cd}$ in $M$. macrocopa causes oxidative stress even at sublethal concentrations, which may be one of the underlying causes of the observed DNA damage. Furthermore, the findings of the present study highlight the importance of utilizing molecular and biochemical biomarkers for toxicity assessment in cladocerans owing to their high sensitivity and rapid responses even under short-term exposure conditions with low concentrations.
\end{abstract}


Heavy metal contamination in aquatic environments is one of the most critical global environmental concerns (Shaw et al. 2006). Among the various heavy metals, cadmium (Cd) can be commonly found in water bodies around the world (Gama-Flores et al. 2017). Natural processes such as weathering and volcanic emissions, as well as domestic, industrial, and other anthropogenic activities can contaminate aquatic environments with $\mathrm{Cd}$ (GamaFlores et al. 2017; Garcia et al. 2004).

$\mathrm{Cd}$ does not have any biological function and it is highly toxic to aquatic organisms even at a concentration of a few micrograms per liter (Shaw et al. 2006; Wang et al. 2009). However, several studies have revealed the occurrence of $\mathrm{Cd}$ in freshwater environments at concentrations above background levels $(0.1-2 \mu \mathrm{g} / \mathrm{L})$ (Barata et al. 2002; Campbell 2006). Freshwater invertebrates and vertebrates are highly susceptible to Cd, which causes a series of changes in cellular homeostasis in organisms at molecular and biochemical levels, such as changes in gene expression, DNA damage, oxidative stress, and interaction with bioelements (Đukić-Ćosić et al. 2020; Gama-Flores et al. 2017; Sadeq and Beckerman 2019; Wang et al. 2018). These sub-organism-level changes can ultimately lead to lethal or sublethal effects such as changes in feeding rate, somatic growth rate, and reproduction at organism levels. This can also lead to changes in population and community structures in aquatic habitats (Barata et al. 2002; Freitas and Rocha 2014). Furthermore, owing to its ability to induce metallothioneins, Cd can be bioaccumulated inside organisms (Fan et al. 2009). Cd accumulated at lower trophic levels can transfer to higher trophic levels through food chains (Ruangsomboon and Wongrat 2006).

Cladocerans, an essential component of freshwater zooplankton, are a useful group of organisms in aquatic toxicological studies for several reasons. Their role as a food link between phytoplankton and fish makes them useful in understanding the trophic dynamics of freshwater bodies (Mangas-Ramírez et al. 2004). Moreover, characteristics such as appropriate body size, sensitivity to toxicants, short generation time, high fecundity, and availability of basic data on culture conditions make them attractive candidates for ecotoxicological studies (Mangas-Ramírez et al. 2004). Furthermore, their parthenogenetic lifecycle results in genetically identical clonal study populations; hence, undesirable genetic differences can be controlled (Barata et al. 2002). Therefore, they are universally employed in routine bioassays of water (Gama-Flores et al. 2007). However, most toxicological studies have been carried out with species belonging to the genus Daphnia, especially Daphnia magna, irrespective of their limited occurrence in tropical water bodies (Gama-Flores et al. 2007; Garcia et al. 2004). Moreover, Sadeq and Beckerman (2019) reported that there is a marked variation in the susceptibility to metals across cladoceran species, where D. magna was found to be the least sensitive species to sublethal concentrations. On the other hand, genera such as Moina and Diaphanosoma show a wide distribution in both tropical and temperate water bodies and they have been less explored in scientific studies (Gama-Flores et al. 2007; Sarma and Nandini 2006). Therefore, the generation of toxicity data on members of these genera will be beneficial (Borase et al. 2019). M. macrocopa is one such widely distributed nontarget freshwater cladoceran, small in size $(\sim 1.0$ $\mathrm{mm}$ ) with a relatively thin carapace having a high sensitivity to pollutants. It is generally short-lived (2-3 weeks) al. 2007; Garcia et al. 2004). 
The limited number of previous reports on Cd toxicity in M. macrocopa in the literature is largely confined to identifying lethal effects (Garcia et al. 2004; Hatakeyama and Yasuno 1981; Pokethitiyook et al. 1987) and the effects of sublethal concentrations of $\mathrm{Cd}$ on life span (Gama-Flores et al. 2007), reproductive rate (Gama-Flores et al. 2007; Hatakeyama and Yasuno 1981; Wong and Wong 1990) generation time (Gama-Flores et al. 2007; Wong and Wong 1990), and population growth (Gama-Flores et al. 2006; Gama-Flores et al. 2007; Garcia et al. 2004; Wong and Wong 1990). In addition, Gama-Flores et al. (2017) have reported the effects of $\mathrm{Cd}$ on transgenerational demographic characteristics (i.e., life expectancy at birth, reproductive rates, generation times, and population increase rate) for multiple generations of Cd-exposed M. macrocopa, and Mangas-Ramírez et al. (2004) reported the recovery patterns of previously Cd-treated M. macrocopa in terms of life history variables (i.e., life span, life expectancy, reproductive rate, generation time, and population increase rate). However, in addition to the individual- and population-level responses, knowledge on subindividual (i.e., molecular and biochemical)-level responses is important as it enables a more realistic assessment of the impacts and provides insight into the causal mechanisms responsible for the effects observed at higher levels of organization (Jemec et al. 2010; Jemec et al. 2007). Furthermore, molecular and biochemical responses can be observed even at low concentrations, and such responses are considered to be rapidly responding endpoints (Jemec et al. 2008). Phromchaloem et al. (2018) have studied nuclear damage in M. macrocopa exposed to a single concentration of $\mathrm{Cd}(160 \mu \mathrm{g} / \mathrm{L})$ by single-cell gel electrophoresis (Comet assay). They observed a significantly higher level of nuclear damage in the treated group than the control group. Other than this work, molecular-level responses of $\mathrm{Cd}$ exposure have not been studied in M. macrocopa. In fact, to our best knowledge, biochemical level responses (e.g., antioxidant enzyme activities) in M. macrocopa upon Cd exposure were not evaluated previously.

Studies have shown that $\mathrm{Cd}$ stimulates the production of reactive oxygen species (ROS) (e.g., superoxide anion $\left(\mathrm{O}_{2}^{\cdot-}\right)$, hydrogen peroxide $\left(\mathrm{H}_{2} \mathrm{O}_{2}\right)$, and hydroxyl radical $\left.\left(\mathrm{OH}^{*}\right)\right)$, which subsequently cause oxidative damage of lipids, proteins, and DNA (Đukić-Ćosić et al. 2020). To minimize the oxidative damage to cellular components, organisms have developed antioxidant defense systems that include several antioxidant enzymes such as catalase (CAT, EC 1.11.1.6) and glutathione S-transferases (GST, EC 2.5.1.18) (Barata et al. 2005). CAT reduces $\mathrm{H}_{2} \mathrm{O}_{2}$ into water and GST catalyzes the conjugation of glutathione (GSH) with various xenobiotics and cytotoxic aldehydes produced during lipid peroxidation (Barata et al. 2005; Jemec et al. 2010). In several freshwater invertebrates, including cladocerans, alterations in the levels of antioxidant enzymes have been observed after exposure to Cd, which is an indication of oxidative stress responses (Barata et al. 2005; Kim et al. 2018; Parolini et al. 2018; Wu et al. 2013; Xie and Buchwalter 2011). In fact, these enzymatic responses are sensitive to very small concentrations of heavy metals including Cd (Kim et al. 2018).

The aim of this study was to determine Cd bioaccumulation in one of the least explored freshwater cladocerans, M. macrocopa, after a short-term exposure to different concentrations of $\mathrm{Cd}$, and to establish relationships between and among $\mathrm{Cd}$ bioaccumulation and more sensitive suborganism-level molecular and biochemical endpoints including DNA alterations and antioxidant enzyme (i.e., CAT, GST) responses, respectively. To visualize and quantify $\mathrm{Cd}$ bioaccumulation, we utilized a novel $\mathrm{Cd}$-sensitive synthetic fluorescence probe that has been successfully used to determine $\mathrm{Cd}$ internalization in an in vitro experiment (Hagimori et al. 2021). DNA alterations were determined using the randomly amplified polymorphic DNA (RAPD) technique. The RAPD 
technique has the potential to detect a variety of DNA damage at the whole genome level and is more sensitive than the Comet assay (Plaire et al. 2013). Furthermore, the variations in whole-body CAT and GST enzyme activities were determined spectrophotometrically to gain an understanding of the oxidative stress responses and the toxicity mechanism of $\mathrm{Cd}$ in $M$. macrocopa. The results of this study provide insight into the dose-response relationships of bioaccumulation, DNA damage, and oxidative stress biomarkers to Cd exposure in M. macrocopa. Furthermore, this study highlights the applicability of molecular and biochemical biomarkers in toxicological assessments conducted with cladocerans.

\section{Materials and Methods}

\section{Laboratory cultures of test organisms and holding conditions}

Female M. macrocopa were initially obtained from a commercial aquarium and successfully cultured in $12 \mathrm{~L}$ glass aquaria at the Applied Ecological Engineering Laboratory, Saitama University, for several generations. Before their use in the experiments, clonal populations of M. macrocopa were established using single healthy parthenogenetic females (Fig. 1a). Clonal cultures were maintained in $1 \mathrm{~L}$ glass beakers with the stocking density controlled at $\sim 100$ individuals per beaker. Aerated ( $\geq 24 \mathrm{~h}$ ) tap water was used as the culture medium and as the dilution water for all exposure experiments. The cultures were fed daily with dry baker's yeast suspension (25 $\mathrm{mg} / \mathrm{mL})$ until the water became cloudy in appearance $(0.5-5 \mathrm{~mL})$.

Regular checkups were carried out in all cultures for any signs of stress conditions (e.g., presence of nonparthenogenetic females (Fig. 1b) and ephippia (Fig. 1c)). The culture medium was renewed twice a week. Cultures were maintained at $22 \pm 2{ }^{0} \mathrm{C}, 7.5 \pm 0.8 \mathrm{pH}, 7.3 \pm 1.2 \mathrm{mg} / \mathrm{L}$ dissolved oxygen, $10.12 \pm 0.66 \mathrm{mS} / \mathrm{m}$ conductivity and $\sim 75 \mathrm{mg} / \mathrm{L}$ hardness as $\mathrm{CaCO}_{3}$ with a photoperiod of a 16:8 light/dark cycle and under gentle aeration. All exposure experiments were conducted with female M. macrocopa neonates ( $<24 \mathrm{~h}$ old) (Fig. 1d) obtained from clonal cultures excluding the first brood progenies.

\section{Acute toxicity tests}

Acute toxicity tests were conducted in accordance with the Organization for Economic Cooperation and Development (OECD) guideline for testing of chemicals No. 202 (OECD 2004). Anhydrous $\mathrm{CdCl}_{2}$ was obtained from FUJIFILM Wako Pure Chemical Corporation, USA (Wako $1^{\text {st }}$ grade). On the basis of the results of a preliminary range finding test, nine test concentrations $(1,5,10,50,100,250,500,750,1000 \mu \mathrm{g} / \mathrm{L})$ were prepared using a $100 \mathrm{mg} / \mathrm{L} \mathrm{Cd}$ stock solution. M. macrocopa neonates $<24 \mathrm{~h}$ old were exposed to each test concentration and dilution water (control) in three replicates per test concentration and control, with 10 individuals per test vessel (glass petri dishes) placed with $25 \mathrm{~mL}$ of test solution. The toxicity tests were conducted at $22 \pm 2{ }^{\circ} \mathrm{C}$ with a 16:8 light/dark photoperiod without aeration for $48 \mathrm{~h}$ under a semistatic renewal condition where the test medium was renewed after $24 \mathrm{~h}$ using freshly prepared stock solution and dilutions. The organisms were not fed during the tests. Survival and immobilization, the latter being defined as incapability of swimming within $15 \mathrm{~s}$ after gentle agitation, were recorded in each test vessel after 24 and $48 \mathrm{~h}$ of exposure. Immobilization results were used to 
calculate the 24- and 48-h $\mathrm{EC}_{50}$ values by probit analysis. Upon the termination of exposure, all surviving individuals (including the immobilized) were used to determine Cd bioaccumulation.

\section{Cadmium bioaccumulation in Moina macrocopa}

A novel fluorescence probe (Fig. 2) with high selectivity towards Cd ions (Hagimori et al. 2021) was used to visualize and quantify Cd bioaccumulation in M. macrocopa. This low-molecular-weight fluorescence probe (MW 218.06) possess a pyridine-pyrimidine core structure that functions as both a $\mathrm{Cd}^{2+}$ coordination site and a fluorophore and produces a fluorescence turn-on response when it binds with $\mathrm{Cd}^{2+}$ (Hagimori et al. 2021).

The surviving $M$. macrocopa neonates exposed to different $\mathrm{Cd}$ concentrations and the control were washed with $0.01 \mathrm{~mol} / \mathrm{L}$ phosphate-buffered saline three times to remove $\mathrm{Cd}$ ions attached to the body surface. The washed neonates were incubated with $100 \mu \mathrm{mol} / \mathrm{L} \mathrm{Cd}$ fluorescence probe prepared in $1 \%$ dimethyl sulfoxide (v/v \%) for $1 \mathrm{~h}$ at $25^{\circ} \mathrm{C}$ in 6-well plates in the dark. After the incubation period, the M. macrocopa neonates were imaged using a fluorescence microscope (BZ-X810, Keyence, Osaka, Japan) with a 4x objective lens, BZ-X filter DAPI (Model OP-87762), and excitation and emission wavelengths at 360/40 and 460/50 nm, respectively. Fluorescence intensities of the images were determined using ImageJ software (National Institutes of Health, USA) with background corrections (Fitzpatrick 2014). For image merging, BZ-X analyzer software (Keyence, Osaka, Japan) was used.

\section{Toxicity tests for the analysis of DNA damage and antioxidant enzymes}

On the basis of the estimated 48-h $\mathrm{EC}_{50}$ values, four sublethal Cd concentrations $(1,5,10$, and $50 \mu \mathrm{g} / \mathrm{L})$, as well as a control, were selected to determine Cd-induced DNA damage and the levels of antioxidant enzymes. Because of the large sample size required for the molecular and biochemical analyses, two consecutive experimentally identical trials were carried out in $200 \mathrm{~mL}$ transparent glass jars with $150 \mathrm{~mL}$ of test solution with 60 neonates of M. macrocopa per replicate and 2-3 replicates for DNA analysis and enzyme assay, respectively. All the other experimental conditions were maintained the same as in the acute toxicity test described above.

\section{Analysis of DNA damage}

\section{Genomic DNA extraction}

At the end of the exposure, total genomic DNA was extracted from $~ 25$ (pooled) surviving M. macrocopa neonates from each test concentration and control (2 replicates). Genomic DNA extraction was carried out under sterile conditions using a DNeasy® blood \& tissue kit (QIAGEN, Hilden, Germany) in accordance with the manufacturer's instructions with slight modifications. Briefly, the neonates were placed in $1.5 \mathrm{~mL}$ microcentrifuge tubes, homogenized in $180 \mu \mathrm{L}$ of buffer ATL and $20 \mu \mathrm{L}$ of proteinase K using a micropestle and mixed by vortexing for $15 \mathrm{~s}$. The samples were then incubated at $56^{\circ} \mathrm{C}$ (Eyela SLI-220, Tokyo, Japan) for $3 \mathrm{~h}$ for tissue lysis with occasional vortexing. At the end of the incubation period, the lysates were vortexed for $15 \mathrm{~s}, 200 \mu \mathrm{L}$ of buffer 
$\mathrm{AL}$ was immediately added, mixed, and again incubated at $56^{\circ} \mathrm{C}$ for 10 minutes. After incubation, $200 \mu \mathrm{L}$ of 99.5\% ethanol was added and mixed by vortexing. The mixtures were pipetted into DNeasy Mini spin columns placed in $2 \mathrm{~mL}$ collection tubes and centrifuged at 6,000 g (KINTARO-18, TOMY, Japan) for $1 \mathrm{~min}$ at room temperature. The flow-through and collection tubes were discarded, and the spin columns were sequentially washed with buffer AW1 $(500 \mu \mathrm{L})$ and buffer AW2 $(500 \mu \mathrm{L})$ by centrifuging at 6,000 $\mathrm{g}(1 \mathrm{~min})$ and $17,000 \mathrm{~g}(3$ $\mathrm{min}$ ) at room temperature, respectively, using new $2 \mathrm{~mL}$ collection tubes each time. The flow-through and collection tubes were discarded each time, and the DNA was eluted into new $1.5 \mathrm{~mL}$ microcentrifuge tubes with $200 \mu \mathrm{L}$ of buffer AE by centrifuging for $1 \mathrm{~min}$ at $6,000 \mathrm{~g}$ after an incubation period of $1 \mathrm{~min}$ at room temperature after adding buffer AE. The DNA purity and concentration were determined using a WPA Biowave DNA Life Science UV/Vis spectrophotometer (Biochrom Cambridge, UK). The software provides the DNA concentration in $\mu \mathrm{g} / \mathrm{mL}$ and the absorption ratios of A260/280 and A260/230 to estimate the DNA purity. Furthermore, the integrity of the extracted DNA was confirmed by capillary electrophoresis The extracted DNA was subjected to RAPD PCR on the same day.

\section{RAPD-PCR analysis}

Cd-induced genotoxicity assessment of M. macrocopa was carried out by the RAPD-DNA technique as described for D. magna, by Atienzar et al. (1999), Atienzar et al. (2001), and Parisot et al. (2015). Ten RAPD primers (10mer oligonucleotides) that were previously used in the genotoxicity assessment of D. magna (Atienzar et al. 2001; Atienzar and Jha 2004) were selected after a preliminary analysis. The primers (Table 1) were obtained from Eurofins Genomics, Tokyo, Japan. The RAPD polymerase chain reaction (PCR) was carried out using the QIAGEN $^{\circledR}$ multiplex PCR plus kit (QIAGEN, Hilden, Germany) in accordance with the manufacturer's instructions with slight modifications. Each reaction mixture contained $25 \mu \mathrm{L}$ of the multiplex PCR master mix, $10 \mu \mathrm{L}$ of the primer mix ( $25 \mathrm{pmol}$ from each primer), and variable volumes of RNase-free water and template DNA (100 ng) to make a final volume of $50 \mu \mathrm{L}$. DNA amplification was carried out on 2720 Thermal Cycler (Applied Biosystems ${ }^{\circledR}$, Thermo Fisher Scientific, USA) with an initial activation at $95^{\circ} \mathrm{C}$ ( 5 min) followed by 45 cycles of denaturation at $95^{\circ} \mathrm{C}(30 \mathrm{~s})$, annealing at $36^{\circ} \mathrm{C}(90 \mathrm{~s})$ and extension at $72^{\circ} \mathrm{C}(90 \mathrm{~s})$. A final extension and a cooling step (until capillary electrophoresis) were carried out at $68^{\circ} \mathrm{C}(10 \mathrm{~min})$ and $15^{\circ} \mathrm{C}$, respectively.

\section{Capillary electrophoresis and analysis of DNA profiles}

The PCR products were electrophoresed with the QIAxcel Advanced instrument (QIAGEN, Hilden, Germany) using the QIAxcel DNA screening kit in accordance with the protocol for the determination of DNA fragment sizes using the QIAxcel ScreenGel Software (QIAGEN, Hilden, Germany). Method AM320 with a sample injection time of $10 \mathrm{~s}$ was employed for the migration parameters. QS DNA Size Marker $100 \mathrm{bp}-2.5 \mathrm{~kb}$ (Cat. 929559) and QS Alignment Marker 15 bp/ 3 kb (Cat. 929522) (QIAGEN, Hilden, Germany) were used to determine DNA fragment sizes. RAPD profiles were analyzed using QIAxcel ScreenGel Software (QIAGEN, Hilden, Germany). 
Genomic template stability (GTS, \%) was estimated in accordance with Atienzar et al. (2001) and Baurand et al. (2015). Briefly, the RAPD profiles of the Cd-treated groups were scored on the basis of different changes observed compared with the control. The changes considered were (1) the appearance of a new band, (2) the disappearance of a band, (3) increased band intensity, and (4) decreased band intensity (Fig. 3). Each change was given an arbitrary value of +1 . GTS $(\%)$ was calculated for each Cd-treated group using,

$$
\operatorname{GTS}(\%)=\left(1-\frac{a}{n}\right) \times 100,
$$

248

where $a$ is the average number of changes observed in a DNA profile, and $n$ is the total number of bands in the control profile.

251

252

\section{Analysis of antioxidant enzymes}

253

Sample preparation

255

At the end of the exposure, the surviving M. macrocopa neonates in each test vessel were washed twice with 100 $\mathrm{mM}$ potassium phosphate buffer of $\mathrm{pH} 7.4$ and 40-50 individuals were pooled from each replicate in $1.5 \mathrm{~mL}$ centrifuge tubes. The pooled individuals were homogenized in $1 \mathrm{~mL}$ of ice-cold potassium phosphate buffer (100 mM, pH 7.4) using an ultrasonic tissue homogenizer (Astrason XL2020, New York, USA). Homogenates were centrifuged at $10,000 \mathrm{~g}$ for $10 \mathrm{~min}$ at $4^{\circ} \mathrm{C}$, and the supernatants were immediately used as the source for enzymes and for protein assays (Barata et al. 2005). Each measurement was performed in triplicate.

262

\section{Catalase}

CAT activity was determined in accordance with Claiborne (1985). The enzyme supernatant (50 $\mu \mathrm{L})$ was mixed with $19 \mathrm{mM}$ hydrogen peroxide $(950 \mu \mathrm{L})$ prepared in $50 \mathrm{mM}$ potassium phosphate buffer of $\mathrm{pH} 7.0$ and the decrease in absorbance at $240 \mathrm{~nm}$ was measured for 2 min using a spectrophotometer (UV-1280, Shimadzu, Kyoto, Japan). CAT activity was expressed as micromoles of hydrogen peroxide consumed per minute per milligram of protein sample ( $\mu \mathrm{mol} / \mathrm{min} / \mathrm{mg}$ protein), taking $0.0436 \mathrm{mM}^{-1} \mathrm{~cm}^{-1}$ as the molar extinction coefficient of hydrogen peroxide.

\section{Glutathione S Transferase}

GST activity was determined in accordance with Habig et al. (1974), as described by Im et al. (2020) for D. magna. 1-Chloro-2,4-dinitrobenzene (CDNB) was dissolved in $15 \mathrm{~mL}$ of ethanol (99.5\%) and diluted to $250 \mathrm{~mL}$ with 100 $\mathrm{mM}$ potassium phosphate buffer ( $\mathrm{pH}$ 6.5) to make a $3 \mathrm{mM}$ stock solution. A solution of reduced glutathione was prepared in $100 \mathrm{mM}$ potassium phosphate buffer $(\mathrm{pH}$ 6.5) to a final concentration of $0.01 \mathrm{M}$. One milliliter of 
phosphate buffer ( $\mathrm{pH}$ 6.5). After adding $50 \mu \mathrm{L}$ of the enzyme supernatant, the increase in absorbance at $340 \mathrm{~nm}$ was measured for $5 \mathrm{~min}$. GST activity was expressed as micromoles of S-2,4dinitrophenyl glutathione conjugate formed per minute per milligram of protein sample ( $\mu \mathrm{mol} / \mathrm{min} / \mathrm{mg}$ protein), taking $9.6 \mathrm{mM}^{-1} \mathrm{~cm}^{-1}$ as the molar extinction coefficient of the conjugate.

\section{Protein}

Protein content of the supernatant was measured using the BCA Protein Assay Kit (Pierce ${ }^{\mathrm{TM}}$, ThermoFisher Scientific) in accordance with the manufacturer's instructions using the standard test tube protocol.

\section{Statistical analysis}

290

All statistical analyses were performed using Minitab ${ }^{\circledR} 19$ statistical software. The data were tested for normality using the Anderson-Darling test at $p<0.05$. One-way analysis of variance (ANOVA) followed by Tukey's post hoc test was conducted to evaluate the statistically significant differences $(p<0.05)$ among $\mathrm{Cd}$ bioaccumulation, GTS (\%), and oxidative stress responses in the control and treated samples.

\section{Results}

297

\section{Survival and immobilization}

Survival percentages of $M$. macrocopa were decreased with increasing $\mathrm{Cd}$ concentration and exposure duration (Fig. 4a), whereas immobilization percentages were increased with increasing $\mathrm{Cd}$ concentration and exposure duration (Fig. 4b). All individuals exposed up to $50 \mu \mathrm{g} / \mathrm{L}$ showed 100\% survival until $48 \mathrm{~h}$ but showed clear signs of immobilization even in the lowest concentration tested $(1 \mu \mathrm{g} / \mathrm{L})$. Control groups did not show any sign of immobilization until the end of the exposure assessment. Neonates exposed to $\mathrm{Cd} \geq 750 \mu \mathrm{g} / \mathrm{L}$ did not survive to $48 \mathrm{~h}$.

On the basis of immobilization data, the 24- and 48-h median effective concentrations $\left(\mathrm{EC}_{50}\right)$ were calculated as 260.84 and 107.64 $\mathrm{Cd} \mu \mathrm{g} / \mathrm{L}$, respectively, using nominal Cd concentrations (Table 2).

\section{Cadmium bioaccumulation}

Bioaccumulation of $\mathrm{Cd}$ in M. macrocopa was estimated using a novel synthetic fluorescence probe that has a high selectivity towards $\mathrm{Cd}$. The probe was previously used to examine $\mathrm{Cd}$ internalization in mouse macrophage cells in vitro (Hagimori et al. 2021).

Analysis of the fluorescence images of live M. macrocopa incubated with the fluorescence probe after treating with different concentrations of $\mathrm{Cd}$ showed a concentration-dependent $\mathrm{Cd}$ bioaccumulation (Figs. 5 \& 6) where a statistically significant fluorescence enhancement was detected in neonates treated with $\geq 5 \mu \mathrm{g} / \mathrm{L}$ compared with 
the control group $(p<0.05)$. However, appreciably higher fluorescence signals were detected in $M$. macrocopa treated with $\geq 100 \mu \mathrm{g} / \mathrm{L}$. As shown by the fluorescence images, clear fluorescence enhancements can be seen in the intestinal tracts of the neonates, indicating that $\mathrm{Cd}$ is localized mostly in the gut region (Fig. 6).

\section{DNA damage}

Referring to the results of the acute toxicity study, four sublethal Cd concentrations $(\sim 50 \%, \sim 10 \%, \sim 5 \%$, and $\sim 1 \%$ of $48 \mathrm{~h}-\mathrm{EC}_{50}$ ) were selected to study the genotoxic effects of $\mathrm{Cd}$ in $M$. macrocopa by the RAPD technique, which is considered as one of the sensitive methods that can detect variations in genome profiles of different organisms (Baurand et al. 2015; Kokina et al. 2020; Maselli et al. 2017).

As Cd concentrations increased, there was an observable corresponding increase in the changes in the RAPD profiles of M. macrocopa. The changes seen in RAPD profiles included the appearance of a new band, disappearance of a normal band, increased band intensity, and decreased band intensity in compared with the RAPD profile of the control group. Bands with such changes were considered as polymorphic bands. The number of polymorphic bands observed in each group treated with different Cd concentrations is given in Table 3 . The largest average number of polymorphic bands (7.5) was observed in neonates treated with $50 \mu \mathrm{g} / \mathrm{L}$ of Cd, where the lowest (2.5) was observed in the neonates treated with $1 \mu \mathrm{g} / \mathrm{L}$ of Cd.

The GTS (\%) of each test group was calculated using the number of polymorphic bands observed in each experimental group. The GTS of the control group was fixed as $100 \%$ and the rest of the GTS values were calculated relative to the control group. M. macrocopa treated with $\geq 10 \mathrm{Cd} \mu \mathrm{g} / \mathrm{L}$ showed significant GTS reductions $(>20 \%$ from the control) $(p<0.05)$ where the highest GTS reduction was observed in the group treated with $100 \mathrm{Cd} \mu \mathrm{g} / \mathrm{L}$ (>30\% from the control) (Fig. 7).

\section{Oxidative stress}

The same set of sublethal Cd concentrations were selected to study oxidative stress enzyme activity responses in M. macrocopa. Activities of two important antioxidant enzyme systems, CAT and GST, which play a major role in ROS-associated stress, were evaluated in each sublethal Cd concentration.

Numerically, a concentration-dependent enhancement of CAT activity was observed; however, statistically, the values were less significantly different from each other $\left(F_{4,10}=3.11, p=0.066\right)$ (Fig. 8a). In contrast, GST activities showed a concentration-dependent enhancement up to $10 \mu \mathrm{g} / \mathrm{L}$ where it was significantly higher than that of the control group $(p<0.05)$ (Fig. 8b). Interestingly, GST activities of the neonates exposed to $50 \mu \mathrm{g} / \mathrm{L}$ showed a significantly lower level $(p<0.05)$, indicating possible GST inhibition at higher concentrations. 
In the present study, the bioaccumulation of $\mathrm{Cd}$ in one of the less explored, yet important freshwater cladocerans, M. macrocopa, was assessed, and associated molecular and biochemical changes (i.e., DNA damage and antioxidant enzyme responses, respectively) were determined in an attempt to understand the mechanism of $\mathrm{Cd}$ toxicity in M. macrocopa.

Since there is little published work on Cd toxicity in M. macrocopa and variation in the limited number of previous findings, the $\mathrm{EC}_{50}$ value on immobilization in $M$. macrocopa was determined using neonates $<24 \mathrm{~h}$ old, where a basic understanding of $\mathrm{Cd}$ toxicity in the organism was obtained. In the present study, the 24- and 48-h $\mathrm{EC}_{50}$ values were estimated as 260.84 and $107.64 \mathrm{Cd} \mu \mathrm{g} / \mathrm{L}$, respectively. In previous studies, Garcia et al. (2004) reported a 24-h $\mathrm{LC}_{50}$ value of $680 \mathrm{Cd} \mu \mathrm{g} / \mathrm{L}$ for neonates $24 \pm 2 \mathrm{~h}$ old, Hatakeyama and Yasuno (1981) reported 48- and 72-h LC $\mathrm{L}_{50}$ values of 71 and $28 \mathrm{Cd} \mu \mathrm{g} / \mathrm{L}$, respectively, for neonates $12 \pm 12 \mathrm{~h}$ old, and Pokethitiyook et al. (1987) reported 24- and 48-h LC 50 values of 218 and $13 \mu \mathrm{g} / \mathrm{L}$, respectively, for neonates $12 \pm 2 \mathrm{~h}$ old. The differences among these toxicity values may have been attributed to the type of endpoint considered (lethality or immobilization), different test media, age of the test organisms, purity of tested heavy metals, different salts of heavy metals, and exposure conditions.

Cd can be bioaccumulated in freshwater organisms including cladocerans (Ruangsomboon and Wongrat 2006). $\mathrm{Cd}$ accumulated by organisms is mostly bound to metallothionein, a low-molecular-weight, cysteine-rich protein. This sequestration of $\mathrm{Cd}$ reduces the amount of free metal ions responsible for toxic effects, and hence is regarded as a method of detoxification (Fan et al. 2009; Hamilton and Mehrle 1986). Nevertheless, the determination of $\mathrm{Cd}$ bioaccumulation is important as it is the link between exposure and toxicity, and it also yields information on the trophic transfer of $\mathrm{Cd}$. In some previous studies, Cd bioaccumulation in M. macrocopa has been determined by measuring Cd-binding protein levels (Yamamura et al. 1983), or by measuring total Cd levels in the body by analytical techniques such as atomic absorption spectrometry (Ruangsomboon and Wongrat 2006; Tan and Wang 2011). However, toxicologically, the free $\mathrm{Cd}$ ions in the body are responsible for toxicological effects. In this regard, fluorescence sensors for metal ions are attractive alternatives (Carter et al. 2014; Hagimori et al. 2015). In the literature, various fluorescence sensors have been developed to target different metal ion, but only a few have been used for the in vivo detection of metal ions in different aquatic organisms. For example, Yang et al. (2007) used a rhodamine-based fluorescence probe to detect mercury ions in zebrafish embryo, He et al. (2019) used an aggregation-induced emission fluorogen to detect the bioaccumulation of mercury ions in the freshwater zooplankton Daphnia carinata, Liu et al. (2016) used a rhodamine-based fluorescence probe to detect palladium ions in zebra fish and D. magna, Liu et al. (2016) used a two-photon ratiometric fluorescence probe to detect zinc ions in zebrafish, and Lv et al. (2020) used a benzopyran-based fluorescence probe to detect the bioaccumulation of mercury ions in zebrafish. In the present study, we used a low-molecular-weight fluorescence probe with a high sensitivity towards $\mathrm{Cd}$ ions, which was previously used to detect cellular Cd ions (Hagimori et al. 2021). The results of the present study indicated a dose-dependent Cd bioaccumulation in M. macrocopa, especially in the gut region. Using radioactively labeled Cd in the exposure media, Carney et al. (1986) found that Cd taken up from solution is concentrated in the exoskeleton of D. magna. In another study, the distribution of radioactively 
labeled Cd was studied in the freshwater cladoceran Ceriodaphnia dubia, and Cd was found to be mainly accumulated in the diverticula of the gut (Munger et al. 1998). In different cladoceran species, the uptake and bioaccumulation patterns of $\mathrm{Cd}$ are different, and it is documented that this is because $\mathrm{Cd}$ is taken up by aquatic organisms as a mimic of $\mathrm{Ca}$ through $\mathrm{Ca}$ uptake pathways, the mechanisms of which differ from species to species (Smirnov 2017; Tan and Wang 2011).

The genotoxicity of $\mathrm{Cd}$ is well documented for several aquatic organisms (Zhang and Reynolds 2019); however, little is known about the genotoxic effects of $\mathrm{Cd}$ in $M$. macrocopa. In the present study, we utilized the RAPD technique to determine the genotoxic effects of $\mathrm{Cd}$ in $M$. macrocopa. In genotoxicity assessment, the most widely used technique is single-cell gel electrophoresis or the Comet assay. Phromchaloem et al. (2018) used the latter technique to determine nuclear damage in M. macrocopa ( $<24 \mathrm{~h}$ old) by exposing them to $160 \mu \mathrm{g} / \mathrm{L}$ for $48 \mathrm{~h}$ and observed significant DNA damage. However, they reported that the nuclear damage was at a minimal level when compared with the results of another study by Pellegri et al. (2014) who observed significant nuclear damage in D. magna exposed to $10 \mu \mathrm{g} / \mathrm{L}$ for $24 \mathrm{~h}$ using the same technique. In the present study, we observed significant DNA damage in $M$. macrocopa exposed to $\geq 10 \mathrm{Cd} \mu \mathrm{g} / \mathrm{L}$ by the RAPD technique. The RAPD technique has been used in several previous studies to determine the genotoxic effects in D. magna exposed to different stressors including heavy metals (Atienzar et al. 2001; Plaire et al. 2013), polycyclic aromatic hydrocarbons (Atienzar et al. 2002; Atienzar and Jha 2004), nano-particles (Maselli et al. 2017), and ionizing radiation (Parisot et al. 2015). In general, the most important advantages of the RAPD technique in genotoxicity assessment are that this technique does not require any prior knowledge of the genome and it has the potential to detect a wide range of DNA damage (e.g., DNA adducts, DNA breakage) and mutations (e.g., insertion, rearrangement, deletion) (Baurand et al. 2015). However, there are some limitations of this method, such as its qualitative or semiquantitative nature, and the possibility of exhibiting same modification of the DNA profile for different types of DNA alterations (Baurand et al. 2015).

Most of the studied mechanisms of Cd-induced DNA alterations are those that are linked with oxidative stress and the ability of $\mathrm{Cd}$ to influence different cellular proteins and their functions in the cell (e.g., DNA damage repair proteins) (Đukić-Ćosić et al. 2020; Zhang and Reynolds 2019). In the present study, the levels of two important antioxidant enzymes (i.e., CAT, GST) were measured to gain insight on the mechanism of the observed DNA damage. To our best knowledge, this is the first report providing information about antioxidant enzyme activities in M. macrocopa upon Cd exposure. CAT activity was found to be increased numerically with increasing exposure concentrations, but these values were less statistically significant from each other. In contrast, GST activities increased significantly up to $10 \mu \mathrm{g} / \mathrm{L}$, but a significant reduction was observed in the neonates exposed to $50 \mu \mathrm{g} / \mathrm{L}$. These results indicate that, although Cd is a redox inactive metal (Đukić-Ćosić et al. 2020), increasing Cd concentration increases the intracellular ROS level. It was observed in previous studies that although Cd does not appear to generate free radicals, lipid peroxidation is elevated in tissues soon after exposure (Barata et al. 2005; Stohs and Bagchi 1995). To minimize the oxidative damage that may be caused by these ROS, antioxidant levels may increase as a detoxification process. Similar patterns of antioxidant responses in other types of cladocerans upon exposure to $\mathrm{Cd}$ have been observed elsewhere. Barata et al. (2005) observed a significant increase in GST activities in D. magna exposed to $5 \mu \mathrm{g} / \mathrm{L} \mathrm{Cd}$ (highest concentration tested) compared with the 
control group. However, in the same study, CAT activities were significantly reduced in $D$. magna exposed to 5 $\mu \mathrm{g} / \mathrm{L} \mathrm{Cd}$. Kim et al. (2018) reported a significant increase in GST activity in D. magna exposed to $10 \mu \mathrm{g} / \mathrm{L} \mathrm{Cd}$ (the highest concentration tested). In support of this finding, the same group reported a significant reduction of GSH content when the exposure Cd concentration was increased. Jemec et al. (2008) reported that there were no significant changes in CAT or GST activities in D. magna exposed to Cd up to $1.31 \mu \mathrm{g} / \mathrm{L}$. However, in the present study, we found that the GST activity in neonates exposed to $50 \mu \mathrm{g} / \mathrm{L}$ is significantly lower than the GST activity in neonates exposed to $10 \mu \mathrm{g} / \mathrm{L}$. This may be an inhibition of GST activity by the high Cd concentration. In fact, $\mathrm{Cd}$ has the ability to bind to thiol (-SH) groups of proteins such as GSH, which is the substrate for GST. This inactivation of GSH will reduce the cellular antioxidant potential and increase the oxidative stress (Kim et al., 2018).

In conclusion, findings from the present study indicated that the bioaccumulation of $\mathrm{Cd}$ in $M$. macrocopa causes oxidative stress even at sublethal concentrations ( $\geq 10 \mathrm{Cd} \mu \mathrm{g} / \mathrm{L}$ ) via the production of ROS, as well as a potential inhibition of cellular antioxidants (i.e., GST) at higher concentrations $(50 \mathrm{Cd} \mu \mathrm{g} / \mathrm{L})$. These oxidative stress responses could be one of the underlying mechanisms of the DNA damage observed in neonates exposed to $\geq 10$ $\mathrm{Cd} \mu \mathrm{g} / \mathrm{L}$. Taken all together, the results of our study improve the understanding of molecular and biochemical responses in one of the least explored freshwater cladocerans, M. macrocopa, upon exposure to Cd. Furthermore, we suggest that the molecular and biochemical endpoints we used in the present study provide more sensitive toxicity details than the lethal and life history variables commonly employed in previous studies, in a shortexposure duration. Therefore, these molecular and biochemical biomarkers could be used for routine toxicity assessments in M. macrocopa. To facilitate further comparisons to expand knowledge about the toxicity of $\mathrm{Cd}$ in M. macrocopa, as well as to compare sensitivity differences with other commonly used species, more research on molecular and biochemical endpoints is needed in future studies.

\section{References}

Atienzar FA, Cheung VV, Jha AN, Depledge MH (2001) Fitness parameters and DNA effects are sensitive indicators of copper-induced toxicity in Daphnia magna. Toxicological sciences 59(2): 241-250. https://doi.org/10.1093/toxsci/59.2.241

Atienzar FA, Conradi M, Evenden AJ, Jha AN, Depledge MH (1999) Qualitative assessment of genotoxicity using random amplified polymorphic DNA: comparison of genomic template stability with key fitness parameters in Daphnia magna exposed to benzo [a] pyrene. Environmental Toxicology and Chemistry: An International Journal 18(10): 2275-2282. https://doi.org/10.1002/etc.5620181023

Atienzar FA, Evenden AJ, Jha AN, Depledge MH (2002) Use of the random amplif| ed polymorphic DNA (RAPD) assay for the detection of DNA damage and mutations: possible implications of confounding factors. Biomarkers 7(1):94-101. https://doi.org/10.1080/13547500110057425

Atienzar FA, Jha AN (2004) The random amplified polymorphic DNA (RAPD) assay to determine DNA alterations, repair and transgenerational effects in B (a) P exposed Daphnia magna. Mutation Research/Fundamental and Molecular Mechanisms of Mutagenesis 552(1-2):125-140. https://doi.org/10.1016/j.mrfmmm.2004.06.009 
Barata C, Baird DJ, Soares AM (2002) Demographic responses of a tropical cladoceran to cadmium: effects of food supply and density. Ecological Applications 12(2):552-564. https://doi.org/10.1890/10510761(2002)012[0552:DROATC]2.0.CO;2

Barata C, Varo I, Navarro JC, Arun S, Porte C (2005) Antioxidant enzyme activities and lipid peroxidation in the freshwater cladoceran Daphnia magna exposed to redox cycling compounds. Comparative Biochemistry and Physiology Part C: Toxicology \& Pharmacology 140(2):175-186. https://doi.org/10.1016/j.cca.2005.01.013

Baurand PE, Capelli N, de Vaufleury A (2015) Genotoxicity assessment of pesticides on terrestrial snail embryos by analysis of random amplified polymorphic DNA profiles. Journal of hazardous materials 298:320327. https://doi.org/10.1016/j.jhazmat.2015.05.051

Borase HP, Muley AB, Patil SV, Singhal RS (2019) Nano-eco toxicity study of gold nanoparticles on aquatic organism Moina macrocopa: As new versatile ecotoxicity testing model. Environmental toxicology and pharmacology 68:4-12. https://doi.org/10.1016/j.etap.2019.02.013

Borase HP, Muley AB, Patil SV, Singhal RS (2021) Enzymatic response of Moina macrocopa to different sized zinc oxide particles: An aquatic metal toxicology study. Environmental Research 194: 110609. https://doi.org/10.1016/j.envres.2020.110609

Campbell PGC (2006) Cadmium - a priority pollutant. Environmental Chemistry 3(6):387-388. https://doi.org/10.1071/EN06075

Carney GC, Shore P, Chandra H (1986) The uptake of cadmium from a dietary and soluble source by the crustacean Daphnia magna. Environmental Research 39(2):290-298. https://doi.org/10.1016/S00139351(86)80055-X

Carter KP, Young AM, Palmer AE (2014) Fluorescent sensors for measuring metal ions in living systems. Chemical reviews 114(8):4564-4601. https://doi.org/10.1021/cr400546e

Claiborne A (1985) Catalase activity. In: Greenwald RA (ed) Handbook of methods for oxygen radical research. CRC press, Boca Raton, pp 283-284

Đukić-Ćosić D, Baralić K, Javorac D, Djordjevic AB, Bulat Z (2020) An overview of molecular mechanisms in cadmium toxicity. Current Opinion in Toxicology 19:56-62. https://doi.org/10.1016/j.cotox.2019.12.002

Fan WH, Tang GE, Zhao CM, Duan Y, Zhang R (2009) Metal accumulation and biomarker responses in Daphnia magna following cadmium and zinc exposure. Environmental Toxicology and Chemistry: An International Journal 28(2):305-310. https://doi.org/10.1897/07-639.1

Fitzpatrick M (2014) Measuring cell fluorescence using ImageJ. In: The Open Lab Book. https://theolb.readthedocs.io/en/latest/imaging/measuring-cell-fluorescence-using-imagej.html

Freitas EC, Rocha O (2014) Acute and chronic toxicity of chromium and cadmium to the tropical cladoceran Pseudosida ramosa and the implications for ecotoxicological studies. Environmental Toxicology 29(2):176-186. https://doi.org/10.1002/tox.20784

Gama-Flores JL, Huidobro-Salas ME, Sarma S, Nandini S (2017) Four transgenerational demographic performance of Moina macrocopa exposed to chronic levels of cadmium. Dose-Response 15(3): 1559325817723732. https://doi.org/10.1177/1559325817723732

Gama-Flores JL, Sarma S, Nandini S (2006) Effect of cadmium level and exposure time on the competition between zooplankton species Moina macrocopa (Cladocera) and Brachionus calyciflorus (Rotifera). 
Journal of Environmental Science and Health Part A 41(6):1057-1070. https://doi.org/10.1080/10934520600620287

Gama-Flores JL, Sarma SSS, Nandini S (2007) Exposure time-dependent cadmium toxicity to Moina macrocopa (Cladocera): a life table demographic study. Aquatic Ecology 41(4):639-648. https://doi.org/10.1007/s10452-007-9121-3

Garcia GG, Nandini S, Sarma SSS (2004) Effect of cadmium on the population dynamics of Moina macrocopa and Macrothrix triserialis (Cladocera). Bulletin of environmental contamination and toxicology 72(4):717-724. https://doi.org/10.1007/s00128-004-0304-5

Habig WH, Pabst MJ, Jakoby WB (1974) Glutathione S-transferases: the first enzymatic step in mercapturic acid formation. Journal of biological Chemistry 249(22):7130-7139. https://doi.org/10.1016/S00219258(19)42083-8

Hagimori M, Karimine Y, Mizuyama N, Hara F, Fujino T. Saji H, Mukai T (2021) Selective cadmium fluorescence probe based on bis-heterocyclic molecule and its imaging in cells. Journal of Fluorescence 31:1161-1167. https://doi.org/10.1007/s10895-021-02748-7

Hagimori M, Mizuyama N, Tominaga Y, Mukai T, Saji H (2015) A low-molecular-weight fluorescent sensor with $\mathrm{Zn}^{2+}$ dependent bathochromic shift of emission wavelength and its imaging in living cells. Dyes and Pigments 113:205-209. https://doi.org/10.1016/j.dyepig.2014.07.032

Hamilton SJ, Mehrle PM (1986) Metallothionein in fish: review of its importance in assessing stress from metal contaminants. Transactions of the American Fisheries Society 115(4):596-609. https://doi.org/10.1577/1548-8659(1986)115<596:MIF>2.0.CO;2

Hatakeyama S, Yasuno M (1981) Effects of cadmium on the periodicity of parturition and brood size of Moina macrocopa (Cladocera). Environmental Pollution Series A, Ecological and Biological 26(2):111-120. https://doi.org/10.1016/0143-1471(81)90041-6

He T, Ou W, Tang BZ, Qin J, Tang Y (2019) In vivo visualization of the process of $\mathrm{Hg}^{2+}$ bioaccumulation in water flea Daphnia carinata by a novel aggregation-induced emission fluorogen. Chemistry - An Asian Journal 14(6):796-801. https://doi.org/10.1002/asia.201801538

Im H, Na J, Jung J (2020) The effect of food availability on thermal stress in Daphnia magna: trade-offs among oxidative stress, somatic growth, and reproduction. Aquatic Ecology 54(4):1201-1210. https://doi.org/10.1007/s10452-020-09804-7

Jemec A, Drobne D, Tišler T, Sepčić K (2010) Biochemical biomarkers in environmental studies-lessons learnt from enzymes catalase, glutathione S-transferase and cholinesterase in two crustacean species. Environmental Science and Pollution Research 17(3):571-581. https://doi.org/10.1007/s11356-0090112-X

Jemec A, Drobne D, Tišler T, Trebše P, Roš M, Sepčić K (2007) The applicability of acetylcholinesterase and glutathione S-transferase in Daphnia magna toxicity test. Comparative Biochemistry and Physiology Part C: Toxicology \& Pharmacology 144(4):303-309. https://doi.org/10.1016/j.cbpc.2006.10.002

Jemec A, Tišler T, Drobne D, Sepčić K, Jamnik P, Roš M (2008) Biochemical biomarkers in chronically metalstressed daphnids. Comparative Biochemistry and Physiology Part C: Toxicology \& Pharmacology 147(1):61-68. https://doi.org/10.1016/j.cbpc.2007.07.006 
Kim H, Kim JS, Kim PJ, Won EJ, Lee YM (2018) Response of antioxidant enzymes to Cd and Pb exposure in water flea Daphnia magna: Differential metal and age-Specific patterns. Comparative Biochemistry and Physiology Part C: Toxicology \& Pharmacology 209:28-36. https://doi.org/10.1016/j.cbpc.2018.03.010

Kokina I, Plaksenkova I, Jermaļonoka M, Petrova A (2020) Impact of iron oxide nanoparticles on yellow medick (Medicago falcata L.) plants. Journal of Plant Interactions 15(1):1-7. https://doi.org/10.1080/17429145.2019.1708489

Liu F, Du J, Xu M, Sun G (2016) A highly sensitive fluorescent sensor for palladium and direct imaging of its ecotoxicity in living model organisms. Chemistry-An Asian Journal 11(1):43-48. https://doi.org/10.1002/asia.201500767

Lv H, Yuan G, Zhang G, Ren Z, He H, Sun Q, Zhang X, Wang S (2020) A novel benzopyran-based colorimetric and near-infrared fluorescent sensor for $\mathrm{Hg}^{2+}$ and its imaging in living cell and zebrafish. Dyes and Pigments 172:107658. https://doi.org/10.1016/j.dyepig.2019.107658

Mangas-Ramírez E, Sarma S, Nandini S (2004) Recovery patterns of Moina macrocopa exposed previously to different concentrations of cadmium and methyl parathion: life-table demography and population growth studies. Hydrobiologia 526(1):255-265. https://doi.org/10.1023/B:HYDR.0000041596.73437.17

Maselli V, Siciliano A, Giorgio A, Falanga A, Galdiero S, Guida M, Fulgione D, Galdiero E (2017) Multigenerational effects and DNA alterations of QDs-Indolicidin on Daphnia magna. Environmental Pollution 224:597-605. https://doi.org/10.1016/j.envpol.2017.02.043

Munger C, Hare L, Craig A, Charest PM (1998) Influence of exposure time on the distribution of cadmium within the cladoceran Ceriodaphnia dubia. Aquatic Toxicology 44(3):195-200. https://doi.org/10.1016/S0166445X(98)00076-9

OECD (2004) OECD Guideline for Testing of Chemicals: Daphnia sp. Acute Immobilisation Test (202). OECD, Paris, France

Parisot F, Bourdineaud JP, Plaire D, Adam-Guillermin C, Alonzo F (2015) DNA alterations and effects on growth and reproduction in Daphnia magna during chronic exposure to gamma radiation over three successive generations. Aquatic Toxicology 163:27-36. https://doi.org/10.1016/j.aquatox.2015.03.002

Parolini M, De Felice B, Ferrario C, Salgueiro-González N, Castiglioni S, Finizio A, Tremolada P (2018) Benzoylecgonine exposure induced oxidative stress and altered swimming behavior and reproduction in Daphnia magna. Environmental Pollution 232:236-244. https://doi.org/10.1016/j.envpol.2017.09.038

Pellegri V, Gorbi G, Buschini A (2014) Comet assay on Daphnia magna in eco-genotoxicity testing. Aquatic Toxicology 155: 261-268. https://doi.org/10.1016/j.aquatox.2014.07.002

Phromchaloem C, Nakphlaiphan A, Piriyamasakul S, Pruksarojanakul W, Pewnim T (2018) Single cell gel electrophoresis of microcrustaceans Moina macrocopa exposed to cadmium. Veridian E-journal Science and Technology Silpakorn University 5(1):36

Plaire D, Bourdineaud JP, Alonzo A, Camilleri V, Garcia-Sanchez L, Adam-Guillermin C, Alonzo F (2013) Transmission of DNA damage and increasing reprotoxic effects over two generations of Daphnia magna exposed to uranium. Comparative Biochemistry and Physiology Part C: Toxicology \& Pharmacology 158(4):231-243. https://doi.org/10.1016/j.cbpc.2013.09.001 
Pokethitiyook P, Upatham E, Leelhaphunt O (1987) Acute toxicity of various metals to Moina macrocopa. Natural History Bulletin of the Saim Society 35:47-56.

Ruangsomboon S, Wongrat L (2006) Bioaccumulation of cadmium in an experimental aquatic food chain involving phytoplankton (Chlorella vulgaris), zooplankton (Moina macrocopa), and the predatory catfish Clarias macrocephalus $\times \quad$ C. gariepinus. Aquatic Toxicology 78(1):15-20. https://doi.org/10.1016/j.aquatox.2006.01.015

Sadeq SA, Beckerman AP (2019) The chronic effects of copper and cadmium on life history traits across Cladocera species: a meta-analysis. Archives of environmental contamination and toxicology 76(1):116. https://doi.org/10.1007/s00244-018-0555-5

Sarma S, Nandini S (2006) Review of recent ecotoxicological studies on cladocerans. Journal of Environmental Science and Health, Part B 41(8):1417-1430. https://doi.org/10.1080/03601230600964316

Shaw JR, Dempsey TD, Chen CY, Hamilton JW, Folt CL (2006) Comparative toxicity of cadmium, zinc, and mixtures of cadmium and zinc to daphnids. Environmental Toxicology and Chemistry: An International Journal 25(1):182-189. https://doi.org/10.1897/05-243R.1

Smirnov N (2017) Physiology of the Cladocera: Academic Press. London, UK

Stohs SJ, Bagchi D (1995) Oxidative mechanisms in the toxicity of metal ions. Free radical biology and medicine 18(2):321-336. https://doi.org/10.1016/0891-5849(94)00159-H

Tan QG, Wang WX (2011) Contrasting patterns of cadmium bioaccumulation in freshwater cladocerans. Limnology and oceanography 56(1):257-267. https://doi.org/10.4319/1o.2011.56.1.0257

Wang M, Zhao W, Jia X, Wei J, Wang S (2018) Eco-toxicology effect on Moina mongolica Daday exposed to $\mathrm{Cd}^{2+}, \mathrm{Pb}^{2+}$, and $\mathrm{Hg}^{2+}$ by the food chain. Environmental Science and Pollution Research 25(16):1602416036. https://doi.org/10.1007/s11356-018-1800-1

Wang Z, Yan C, Zhang X (2009) Acute and chronic cadmium toxicity to a saltwater cladoceran Moina monogolica Daday and its relative importance. Ecotoxicology 18(1):47-54. https://doi.org/10.1007/s10646-0080255-4

Wong CK, Wong PK (1990) Life table evaluation of the effects of cadmium exposure on the freshwater cladoceran, Moina macrocopa. Bulletin of environmental contamination and toxicology 44(1):135-141. https://doi.org/10.1007/BF01702373

Wu H, Xuan R, Li Y, Zhang X, Wang Q, Wang L (2013) Effects of cadmium exposure on digestive enzymes, antioxidant enzymes, and lipid peroxidation in the freshwater crab Sinopotamon henanense. Environmental Science and Pollution Research 20(6):4085-4092. https://doi.org/10.1007/s11356-0121362-6

Xie L, Buchwalter DB (2011) Cadmium exposure route affects antioxidant responses in the mayfly Centroptilum triangulifer. Aquatic Toxicology 105(3-4):199-205. https://doi.org/10.1016/j.aquatox.2011.06.009

Yamamura M, Hatakeyama S, Suzuki KT (1983) Cadmium uptake and induction of cadmium-binding protein in the waterflea (Moina macrocopa). Bulletin of environmental contamination and toxicology 30(1):298302.

Yang YK, Ko SK, Shin I, Tae J (2007) Synthesis of a highly metal-selective rhodamine-based probe and its use for the in vivo monitoring of mercury. Nature Protocols 2(7):1740-1745. https://doi.org/10.1038/nprot.2007.246 
Zhang H, Reynolds M (2019) Cadmium exposure in living organisms: A short review. Science of the Total Environment 678:761-767. https://doi.org/10.1016/j.scitotenv.2019.04.395

639

Statements and Declarations

640

641

\section{Funding}

642

643 This research was funded by the Research Center for Sustainable Development in East Asia, Saitama University 644 (V3060SR3) and scholarship donation, Saitama University (KF1T253364).

645

646

\section{Competing Interests}

647

648

The authors declare that they have no financial or non-financial interests to disclose.

649

650

Author Contributions

651

652 Takeshi Fujino and Thilomi Samarakoon conceptualized and designed the experiment. Experiments and data 653 analyses were performed by Thilomi Samarakoon under the supervision of Takeshi Fujino. The novel Cd selective 654 fluorescence probe was provided by Masayori Hagimori. Rie Saito assisted in DNA analysis. The first draft of the 655 manuscript was written by Thilomi Samarakoon, and all authors have commented on previous versions of the 656 manuscript. All authors read and approved the final manuscript.

657

658

Data Availability

659

660 The data generated and analyzed during this study will be available upon proper request to the corresponding 661 author.

662 


\section{Figures}

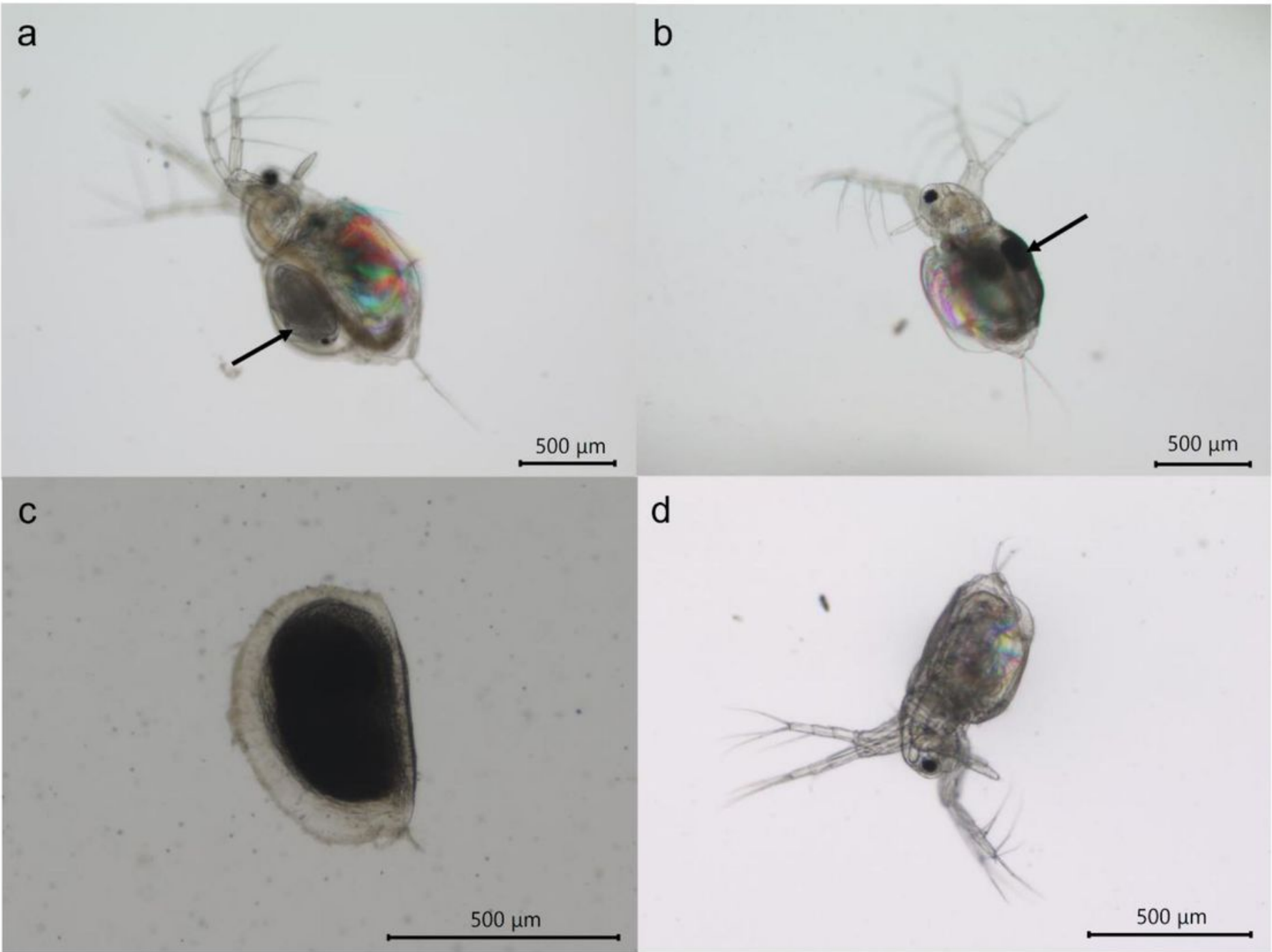

Fig. 1 M. macrocopa from laboratory cultures: (a) parthenogenetic (asexual) female with the brood pouch, (b) non-parthenogenetic (sexual) female with ephippia, (c) a free ephippium, and (d) neonate $<24$ h old

\section{Figure 1}

Please See image above for figure legend. 


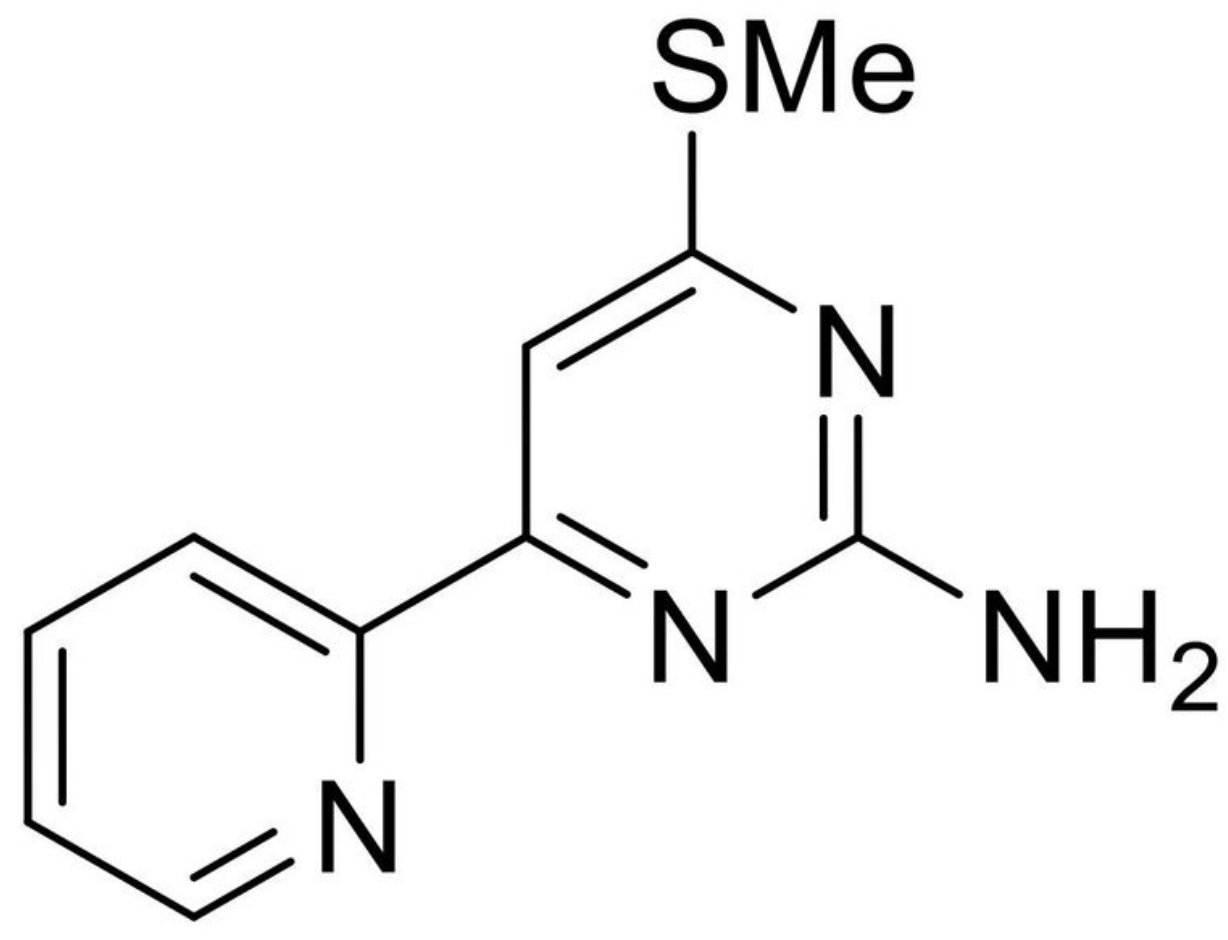

Fig. 2 4-(Methylsulfanyl)-6-(pyridin-2-yl)pyrimidin-2-amine $(\lambda$ ex $=334 \mathrm{~nm}, \lambda$ em $=412 \mathrm{~nm})$

Figure 2

Please See image above for figure legend. 


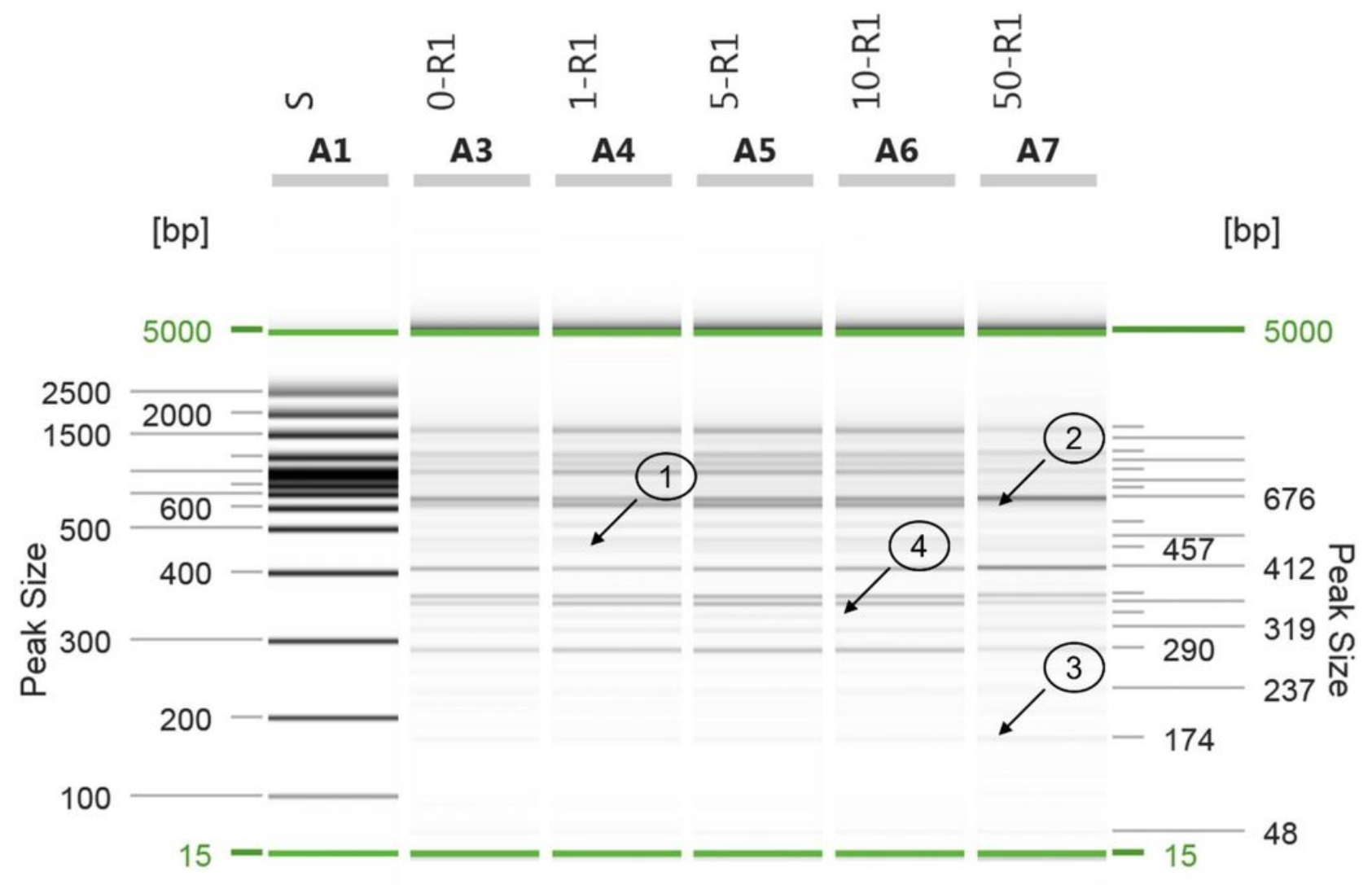

Fig. 3 Example of RAPD profile of M. macrocopa treated with different concentrations of Cd $(0-50 \mu \mathrm{g} / \mathrm{L})$. Different numbers indicate different changes compared with the control: (1) appearance of a new band, (2) disappearance of a new band, (3) increased band intensity, and (4) decreased band intensity.

\section{Figure 3}

Please See image above for figure legend. 


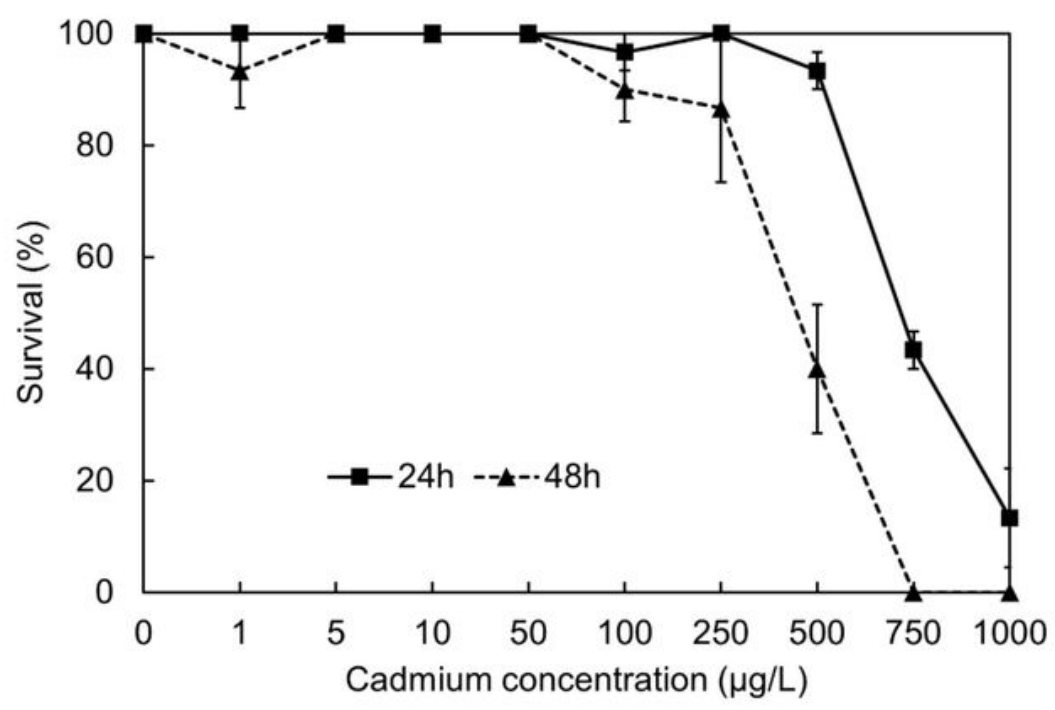

b

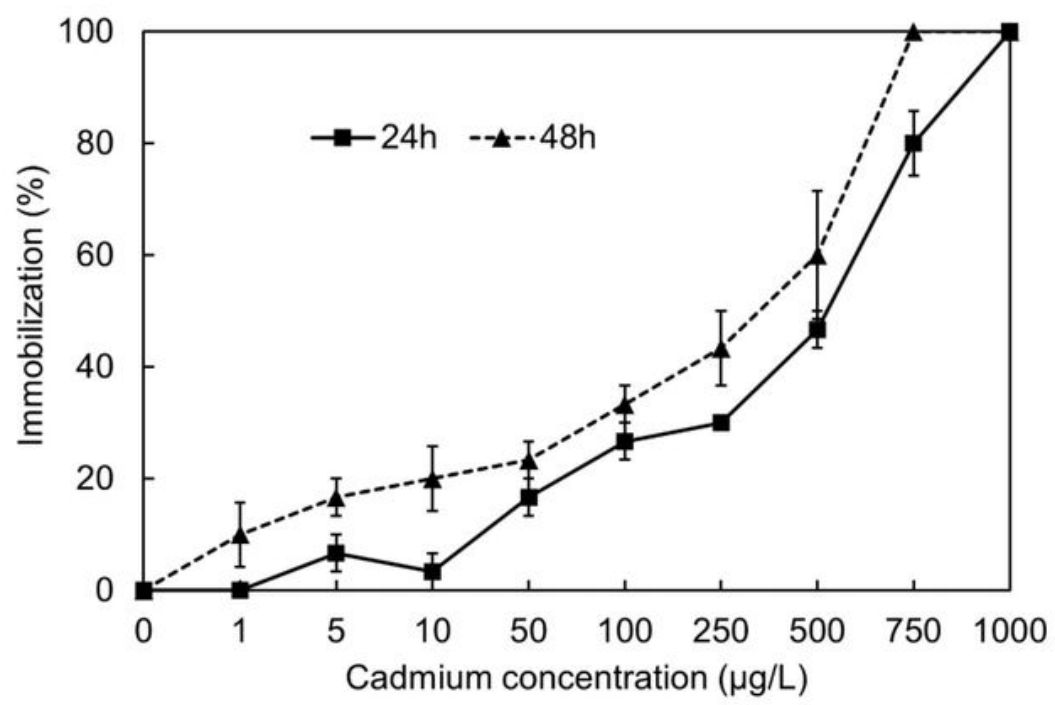

Fig. 4 (a) Survival percentages and (b) immobilization percentages of $M$. macrocopa neonates exposed to different concentrations of $\mathrm{Cd}$ for $48 \mathrm{~h}$. Data are presented as mean \pm SEM from three replicates ( $n=10$ per replicate).

\section{Figure 4}

Please See image above for figure legend. 


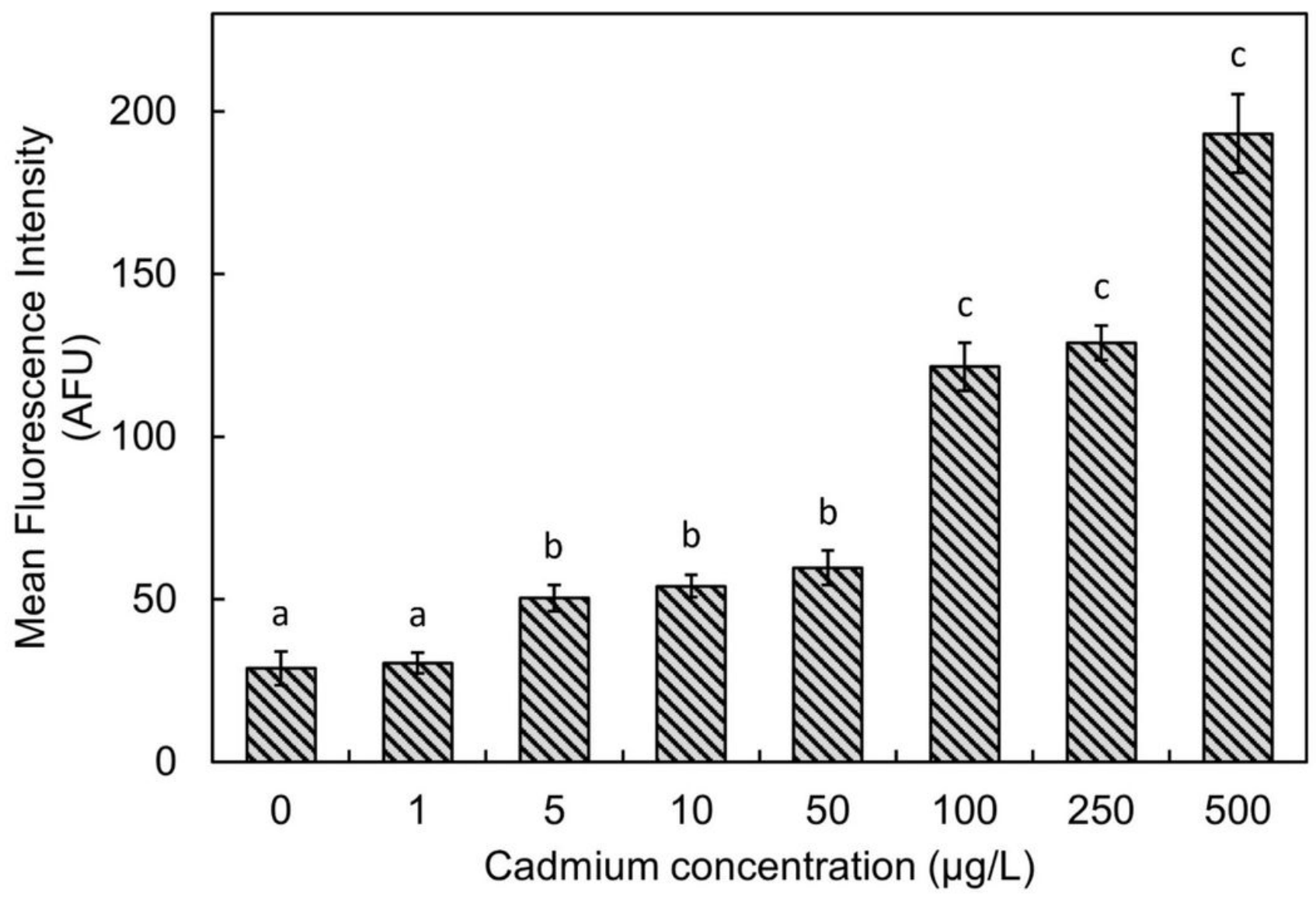

Fig. 5 Fluorescence intensities of the fluorescence images of M. macrocopa neonates exposed to $\mathrm{Cd}(0-500 \mu \mathrm{g} / \mathrm{L})$ for $48 \mathrm{~h}$ followed by incubation with the Cd-sensitive fluorescence probe for $1 \mathrm{~h}$. Data are presented as mean \pm SEM from three replicates ( $n=5$ per replicate). In each concentration, mean values with different letters are significantly different from each other $(p<0.05)$.

Figure 5

Please See image above for figure legend. 


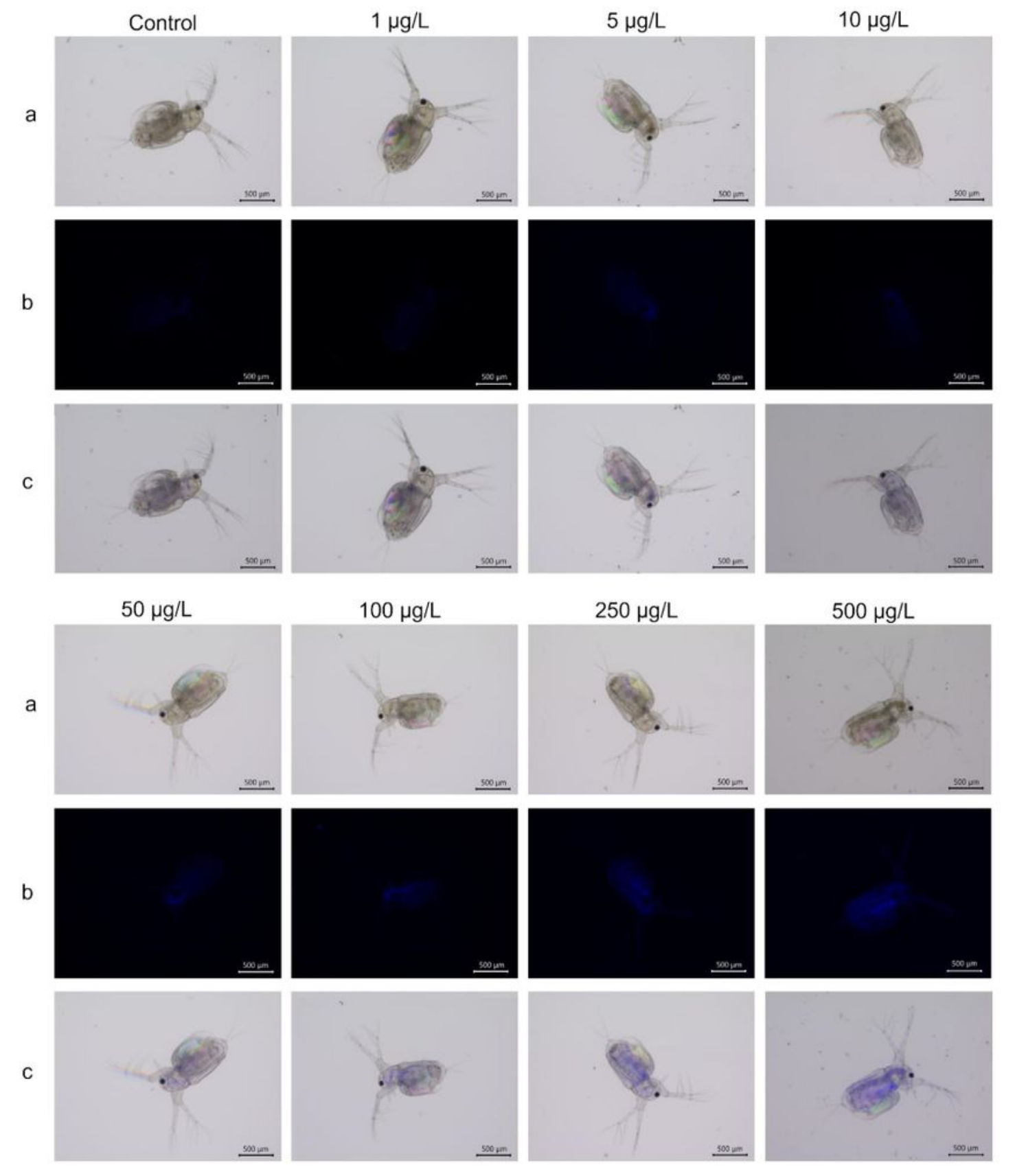

Fig. 6 (a) Brightfield, (b) fluorescence, and (c) merged images of $M$. macrocopa treated with different concentrations of $\mathrm{Cd}(0-500 \mu \mathrm{g} / \mathrm{L})$ for $48 \mathrm{~h}$ followed by $1 \mathrm{~h}$ incubation with $100 \mu \mathrm{mol} \mathrm{Cd}$ fluorescence probe.

\section{Figure 6}

Please See image above for figure legend. 


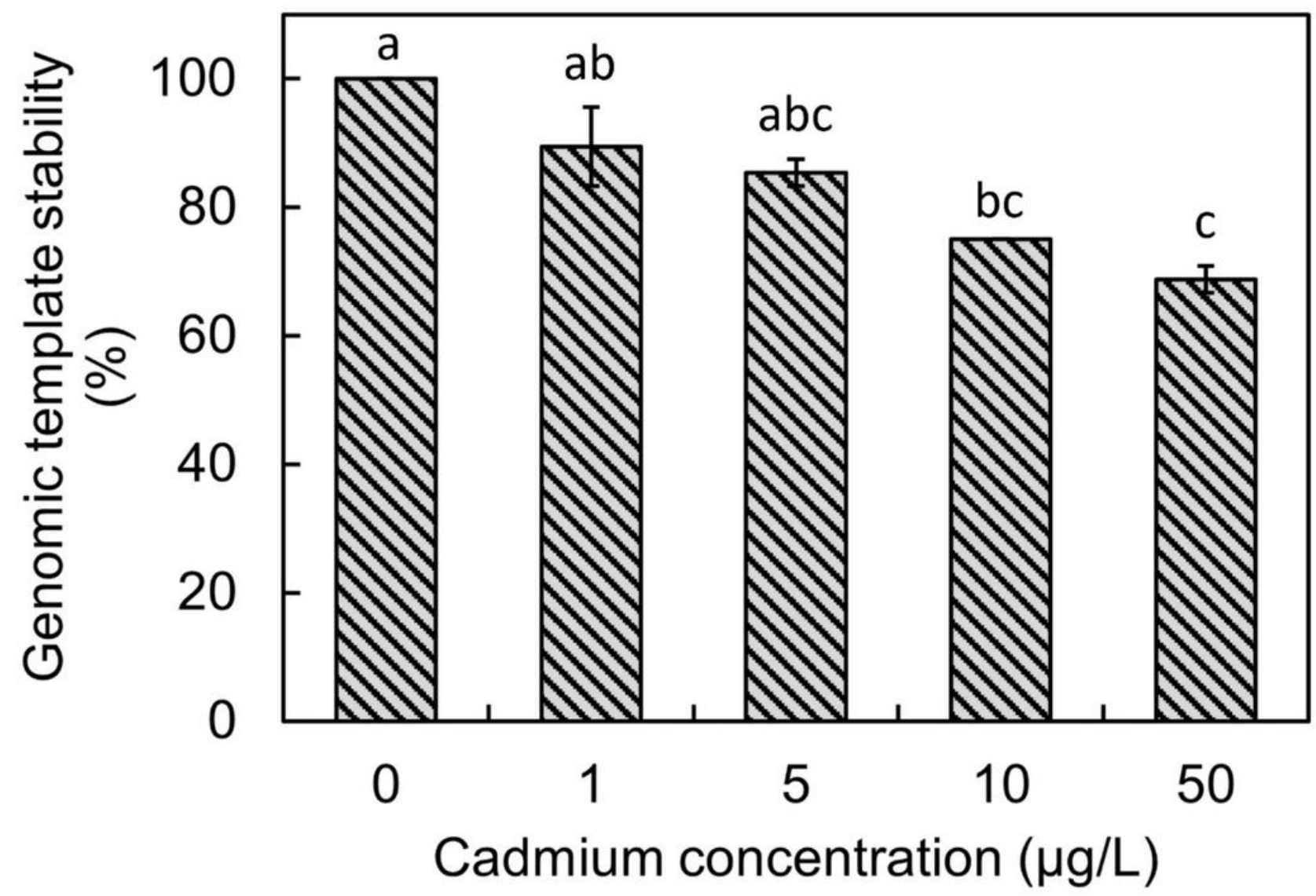

Fig. 7 GTS (\%) of M. macrocopa neonates after $48 \mathrm{~h}$ exposure to different sublethal concentrations of $\mathrm{Cd}(0-50$ $\mu \mathrm{g} / \mathrm{L}$ ). Data are presented as mean \pm SEM from two replicates ( $n=25$ pooled per replicate). Mean values with different letters are significantly different from each other $(p<0.05)$.

Figure 7

Please See image above for figure legend. 


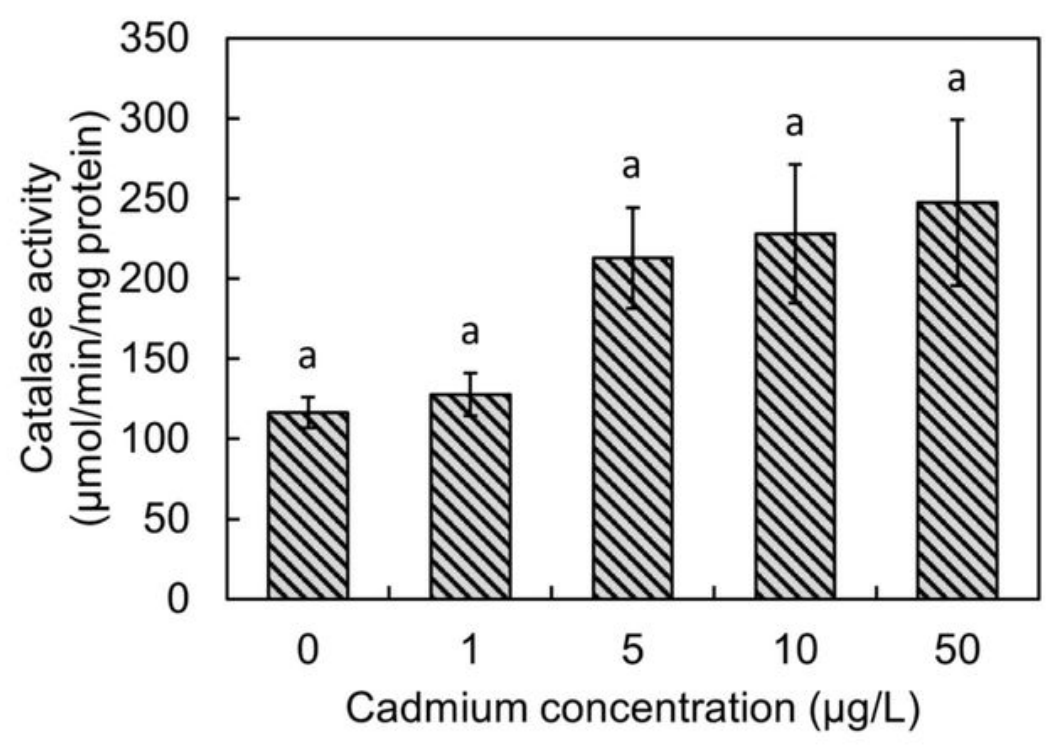

b

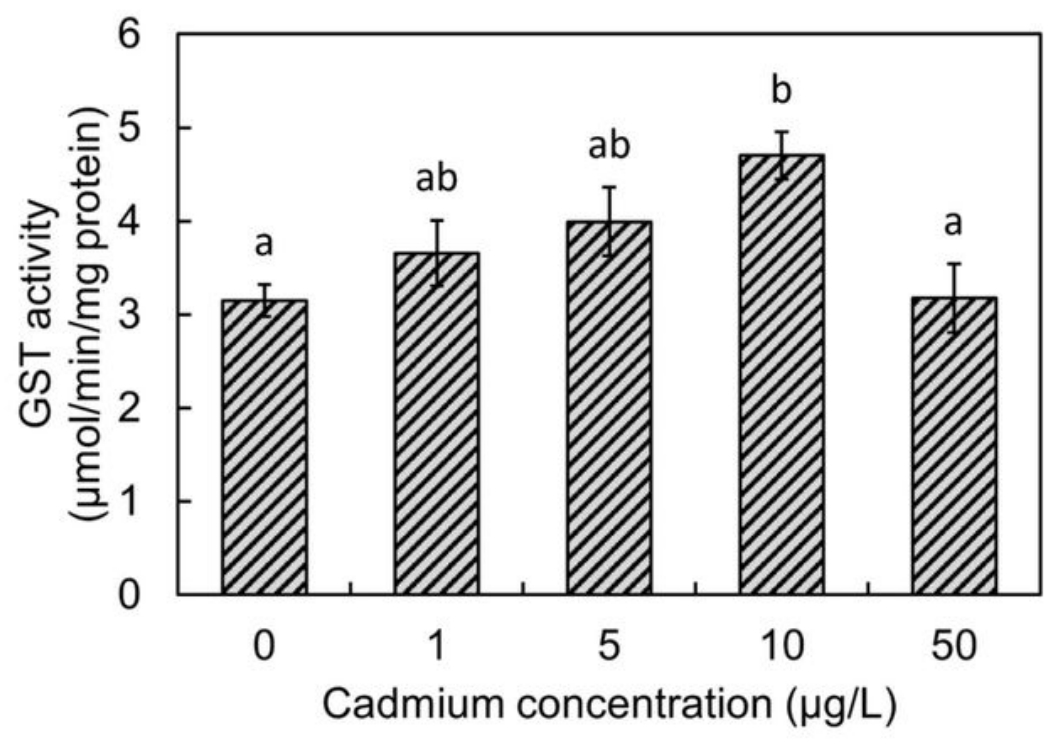

Fig. 8 (a) CAT and (b) GST activities in M. macrocopa neonates exposed to different sublethal Cd concentrations $(0-50 \mu \mathrm{g} / \mathrm{L})$ for $48 \mathrm{~h}$. Data are presented as mean \pm SEM from three replicates ( $n=40-50$ pooled per replicate). Mean values with different letters are significantly different from each other $(p<0.05)$.

Figure 8

Please See image above for figure legend.

\section{Supplementary Files}

This is a list of supplementary files associated with this preprint. Click to download. 
- SamarakoonTTables.pdf 